\title{
114 動吸振器を利用したカメラ内部ミラーモデルの振動抑制
}

\section{Vibration Reduction for the Internal Mirror of a SLR Camera by a Dynamic Absorber}

\author{
○正 松本大樹 （室蘭工大） 正 斉当建一（室蘭工大） 近藤健太（フジキン） \\ Hiroki MATSUMOTO, Muroran Institute of Technology , 27-1 Mizumoto-cho, Muroran-shi, Hokkaido \\ Ken-ichi SAITOH, Muroran Institute of Technology \\ Kenta KONDOH , Fujikin Incorporated
}

Key Words: Vibration reduction, Dynamic absorber, SLR Camera, Rebound

\section{1 緒言}

一眼レフカメラは，プロ用も含めて様々な用途で古くから利 用されている。現状ではその多くがデジ夕ル化されているが, 基本的な機構は大きくは変わらない，すなわち，被写体からの 光線はレンズを通った後, 内部ミラーにより, ファインダーと オートフォーカス用の素子の 2 方向に分光され，オートフォー カスが行われるのと同時にファインダーでその様子を肉眼で確 認するこにができるようになっている，次にシャッターボタン が押されると, 内部ミラーは上方に跳ね上がって, 被写体から の光線をフィルム，もしくは CCDへと通過させる。その瞬間， ファインダーは一度ブラックアウトし, 感光 $(\mathrm{CCD}$ へ記録) が終了すると，ミラーは再び元の位置に戻り，次のコマの撮影 の準備に入る。この際にミラーは，ミラーの初期位置を決める ストッパーへと高速に衝突することとなり，その反動で跳ね返 ることがある。この跳权返りが抑制できない場合，被写体から の光線は正常にオートフォーカス素子へ導かれず，ピントを合 わせることができなくなる。つまり，ミラーの跳ね返りが収ま らないと次のコマの撮影ができない夕イムラグが生じることに なる、これまで高速な連続撮影の実現のために，振動を押さえ る様々な工夫がなされてきたが, その機構は複雑で比較的高コ ストである，そこで，本研究ではミラーの跳ね返り振動を動吸 振器を利用して抑制することを目的に，コンパクトかつ低コス 卜な振動抑制手法を提案する。本報告では, 動吸振器の最適な 質量，ばね定数および減衰係数を検討した結果を報告する。

\section{2 ミラーモデル}

本研究では, 動吸振器の効果を確かめるために, 実際の内部 ミラーとほぼ同じ大きさのアルミニウム製のモデルを制振対象 とする. また，ミラーは実機ではばね力によって駆動されるこ とになるが,ここでは水平位置より自由落下させてストッパー に衝突させる，その際の跳ね返り量が小さくなるような動吸振 器を検討する. Fig.1 にミラーモデルの跳ね返り量の計測状況を 示す。ミラーモデルは 固定軸方向の幅 $40 \mathrm{~mm}$ ，高さ $30 \mathrm{~mm}$ ，厚 さ $1 \mathrm{~mm}$ の長方形平板で，Fig.1 に示すように一端を直径 $2 \mathrm{~mm}$ の軸によって回転支持されている. 水平位直よりミラーが $45 \mathrm{deg}$ の位置を原点とし，水平位置から自由落下させ，その際に跳ね 返った変位をレーザー変位計により計測し, 角度に変換して評 価する. 計測位置はミラーモデルの中央上端から $5 \mathrm{~mm}$ の位置 である. 計測值は 10 回の平均值を用いている。ストッパーの位 置は，ミラーモデル前面右端を原点とし，前辺を $20 \mathrm{~mm}$ まで， 右辺 $10 \mathrm{~mm}$ までを $1 \mathrm{~mm}$ 間隔で変化させた. ストッパーはジュ ラルミン製の直径 $4 \mathrm{~mm}$ の円柱であり，円筒面でミラーモデル と接触させた。

ミラーモデルを水平位置から自由落下させると，回転してス トッパーと衝突する，その後は，Fig.（3）のように，跳ね上が りと自由落下を繰り返す挙動となる.ここでは，ミラーモデル に対してインパルスカが繰り返し㗢く力学系と考え，インパル ス力の入力後の応答ができるだけ小さくなるように，ミラーモ

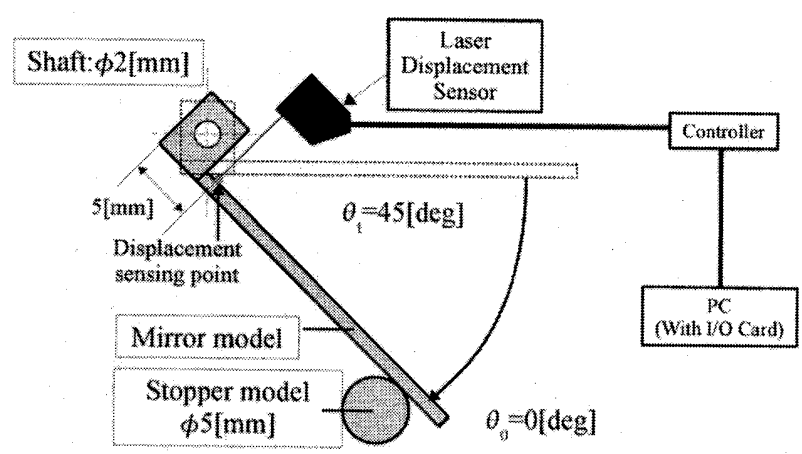

Fig.1 Experimental setup

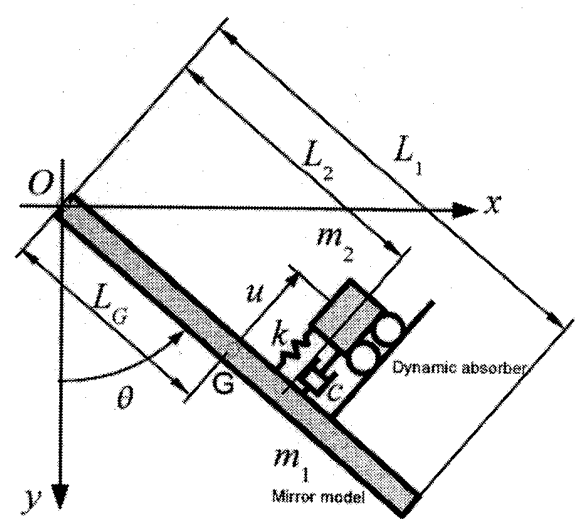

Fig.2 Schematic diagram of a mirror model

デルの周波数応答を求めることで，抑制効果を検討する.

\section{3 理論解析}

ミラーモデルの挙動を一次元の回転運動とし，動吸振器をミ ラーモデル上で直線運動すると仮定する. Fig.2 に力学モデルを 示す. 図中に示すようにミラーモデルの質量を $m_{1}$, 動吸振器の 質量を $m_{2}$ とし, 動吸振器のばねのばね定数を $k$, 粘性減衰係数 を $c$ とする. ミラーモデルの全長を $L_{1}$, 動吸振器の取り付け位 置を $L_{2}$, ミラーモデルの重心の位置を $L_{G}$ とする. 動吸振器は ミラーモデルと垂直方向に動くものとして，その変位を $u$ とす る.ミラーモデルは鉛直下向きを原点として半時計回りに回転 角 $\theta$ でその位置を示す。

ミラーモデルと動吸振器，それぞれの運動エネルギー，ポテ ンシャルエネルギーおよび散逸関数を求めると,

$$
\begin{aligned}
& T=\frac{1}{2} I \dot{\theta}^{2}+\frac{1}{2} m_{2}\left(L_{2} \dot{\theta}^{2}+\dot{u}^{2} u^{2} \dot{\theta}^{2}+2 L_{2} \dot{u} \dot{\theta}\right) \\
& U=m_{1} g L_{G}(1-\cos \theta)+m_{2} g\left\{L_{2}(1-\cos \theta)+u \sin \theta\right\}+\frac{1}{2} k u^{2}
\end{aligned}
$$




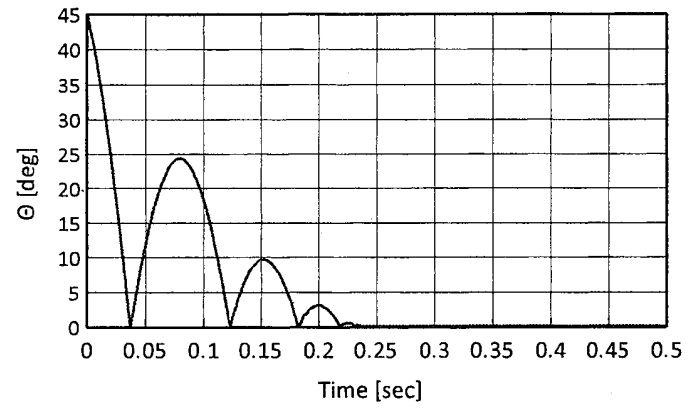

Fig.3 Rebound vibration of a mirror model

$$
F=\frac{1}{2} c \dot{u}^{2}
$$

周波数応答を求めるために，ミラーモデルに周期的外力が作 用すると仮定して, ラグランジュの運動方程式を考え, 整理す ると,

$$
\begin{array}{r}
I \ddot{\theta}+m_{2}\left(L_{2}^{2} \ddot{\theta}+2 u \dot{u} \dot{\theta}+u^{2} \ddot{\theta}+L_{2} \ddot{\ddot{u}}\right)+m_{1} g L_{G} \sin \theta \\
+m_{2} g\left(u \cos \theta+L_{2} \sin \theta\right)=P L_{G} e^{j \omega t} \\
m_{2}\left(L_{2} \ddot{\theta}+\ddot{u}\right)+m_{2} g \sin \theta-m_{2} u \dot{\theta}^{2}+c \dot{u}+k u=0
\end{array}
$$

これよりミラーモデルの角振幅を求め, 無次元化すると

$$
\left|\frac{\Theta}{\Theta_{s t}}\right|=\sqrt{\frac{A^{2}+4 \zeta^{2} B^{2}}{C^{2}+4 \zeta^{2} D^{2}}}
$$

ここで,

$$
\left.\begin{array}{l}
A=f^{2}-h^{2} \\
B=h \\
C=\frac{4}{3} h^{4}-h^{2}\left(1+\frac{4}{3} f^{2}+f^{2} \mu \gamma^{2}-\mu \gamma\right)+f^{2}+f^{2} \mu \gamma-\mu \\
D=h\left\{-h^{2}\left(\frac{4}{3}+\mu \gamma f^{2}\right)+1+\mu \gamma\right\}
\end{array}\right\}(7)
$$

さらに

$$
\left.\begin{array}{llll}
\mu=\frac{m_{2}}{m_{1}}, & \gamma=\frac{L_{2}}{L_{G}}, & \Omega^{2}=\frac{g}{L_{G}} & \omega_{a}^{2}=\frac{k}{m_{2}} \\
\zeta=\frac{c}{2 m_{2} \Omega}, & f=\frac{\omega_{a}}{\Omega}, & h=\frac{\omega}{\Omega}, & \Theta_{s t}=\frac{P}{m_{1} g}
\end{array}\right\}
$$

である。

\section{4 最適化}

式（6）は一般的な動吸振器モデルでの主系の振幅にあたり, この各加振周波数に対して最小になるように，付加系の質量お よび主系との接続に用いられるばね定数, 粘性減衰係数を決定 する(1). まず始めに, 式 (6) において減衰比 $\zeta=\infty と \zeta=0$ の 場合の 2 本の共振曲線の交点である不動点での無次元加振周波 数 $h_{p}, h_{Q}$ を決定する，次にそのときの高さが最大值になるよう に付加系の固有振動数, すなわち， $f$ を決定する.さらに, $\mathrm{P}$, $\mathrm{Q}$ 点で応答倍率が極大值になるように, $h$ による偏微分值が 0 にある条件を当てはめて，減衰比を求める，その結果，得られ た固有振動数比は

$$
f=\frac{\sqrt{12+24 \mu}}{4+3 \mu \gamma^{2}}
$$

であり，P 点が極大値になる場合の減衰係数は

$$
\zeta_{P}=\frac{1}{2} \sqrt{\frac{A A^{\prime}-\left|\frac{\Theta}{\Theta_{s t}}\right|^{2} C C^{\prime}}{-B B^{\prime}+\left|\frac{\Theta}{\Theta_{s t}}\right|^{2} D D^{\prime}}}
$$

である。ここで, 「」は $h$ に関する偏微分を表している。この $\zeta_{P}$ は $Q$ 点と值が若干異なるが，相加平均を用いて最適な值を 求める.

\section{5 計算結果}

Fig.4 に計算結果を示す. $\mu=0.2, \gamma=0.5$ の場合で, 最適 調整を行った結果である.ミラーモデルをアルミニウム（質量 $3.27 \mathrm{~g})$ とすると, 動吸振器に質量は $0.6 \mathrm{~g}$, 取り付け位置は回転

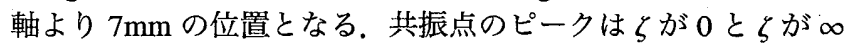
の場合のグラフの交点付近に現れ，最適調整により適切な $\omega_{a}$, らが選択されていることがわかる。

次に, Fig.5 に動吸振器の取り付け位置を変化させて計算し

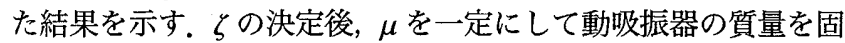
定し， $\gamma$ を変化させその取り付け位置の影響を検討する. Fig.5 に計算結果を示す. $\gamma$ が小さくなるほど応答倍率は小さくなり, 動吸振器の効果が高くなる傾向がある。このことから, 動吸振 器の取り付け位置は，ミラーモデルの重心より固定軸方向にで きるだけ離して取り付けたほうが動吸振器の効果が高くなるこ とがわかるが，実際にはむやみに近づけることができないため， 0.2 以下にすることはできないと思われる.

\section{6 結言}

本検討よってミラーの振り子運動を抑制するための動吸振器 の取り付け位置は，ミラーの重心よりも回転軸寄りに取り付け ることで，抑制効果が高くなることがわかった。これにより周 波数応答の応答振幅は小さくなり，跳称返り現象においても跳 ね返り量が小さくなることが期待できる，今後実験により検証 を進める. 動吸振器のモデルは実体と異なるため, より実際に 近づくようモデルの再検討も進めていく予定である。

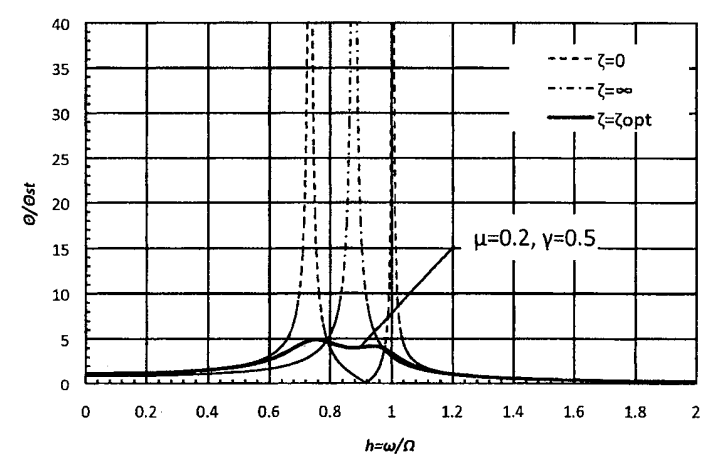

Fig.4 Resonance curve of mirror model with a dynamic absorber.

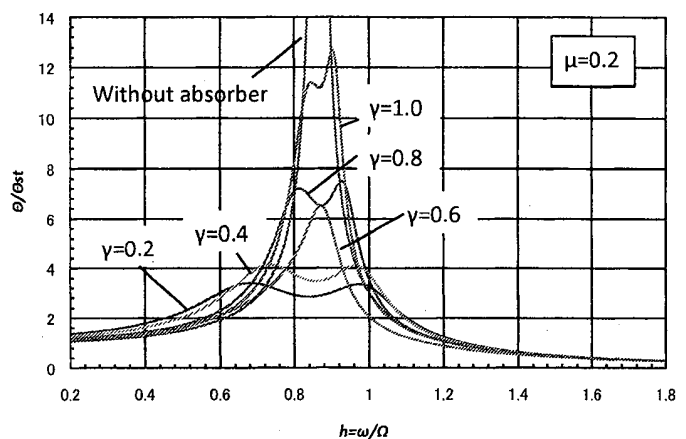

Fig.5 Effect of parameta $\gamma$ on the resonance curve.

\section{参考文献}

（1）松久寛，顧栄栄，王永金，西原修，佐藤進，機論，59-562，C(1993)，1717 